Prepared in cooperation with the Puerto Rico Aqueducts and Sewers Authority, Puerto Rico Department of Natural and Environmental Resources, and Puerto Rico Environmental Quality Board

\title{
Source, Use, and Disposition of Freshwater in Puerto Rico, 2005
}

\section{Introduction}

Water diverted from streams and pumped from wells constitutes the main sources of water for the 78 municipios of the Commonwealth of Puerto Rico (fig. 1). A better understanding is needed about water-use patterns, particularly about the amount of water used, where and how this water is used and disposed, and how human activities impact water resources. Irrigation practices, indoor and outdoor household uses, industrial uses, and commercial and mining withdrawals affect reservoirs, streams, and aquifers. Accurate and accessible water information for Puerto Rico is critical to ensure that water managers have the ability to protect and conserve this natural resource.

The population of Puerto Rico increased 15 percent, from 3.4 million in 1985 to 3.9 million people 2005 and resulted in an increased demand for freshwater, mostly for the publicsupply water use category. Almost 99 percent of the residents in Puerto Rico were served by public-supply water systems in 2005. One of the major challenges that water managers confront is the need to provide sufficient freshwater availability in the densely populated areas. Public-supply water is provided by the Puerto Rico Aqueducts and Sewers Authority (PRASA) and by non-PRASA systems. Non-PRASA systems refer to community-operated water systems (water systems that serve a rural or suburban housing area).

\section{Sources of Water}

Water-use data and concepts presented in this factsheet refer only to offstream uses. Offstream use is the freshwater diverted or withdrawn from a surface -water or groundwater source and conveyed to the place of use. Offstream use is sometimes referred to as withdrawal use. Instream use refers to water that is used, but not withdrawn, from ground or surface- water sources for such purposes as thermoelectricsaline withdrawals and hydroelectric power.

In 2005, a total of 722 million gallons per day (Mgal/d) of freshwater was processed in Puerto Rico to satisfy the demand of approximately 3.9 million of people (U.S. Census Bureau, 2006). Puerto Rico has only three main natural sources of freshwater: groundwater, surface water, and desalinated water. Because desalinated water represents less than 1 percent of the total freshwater withdrawals, it is not considered in this analysis. For the purpose of this factsheet, public-supply water is a freshwater source.

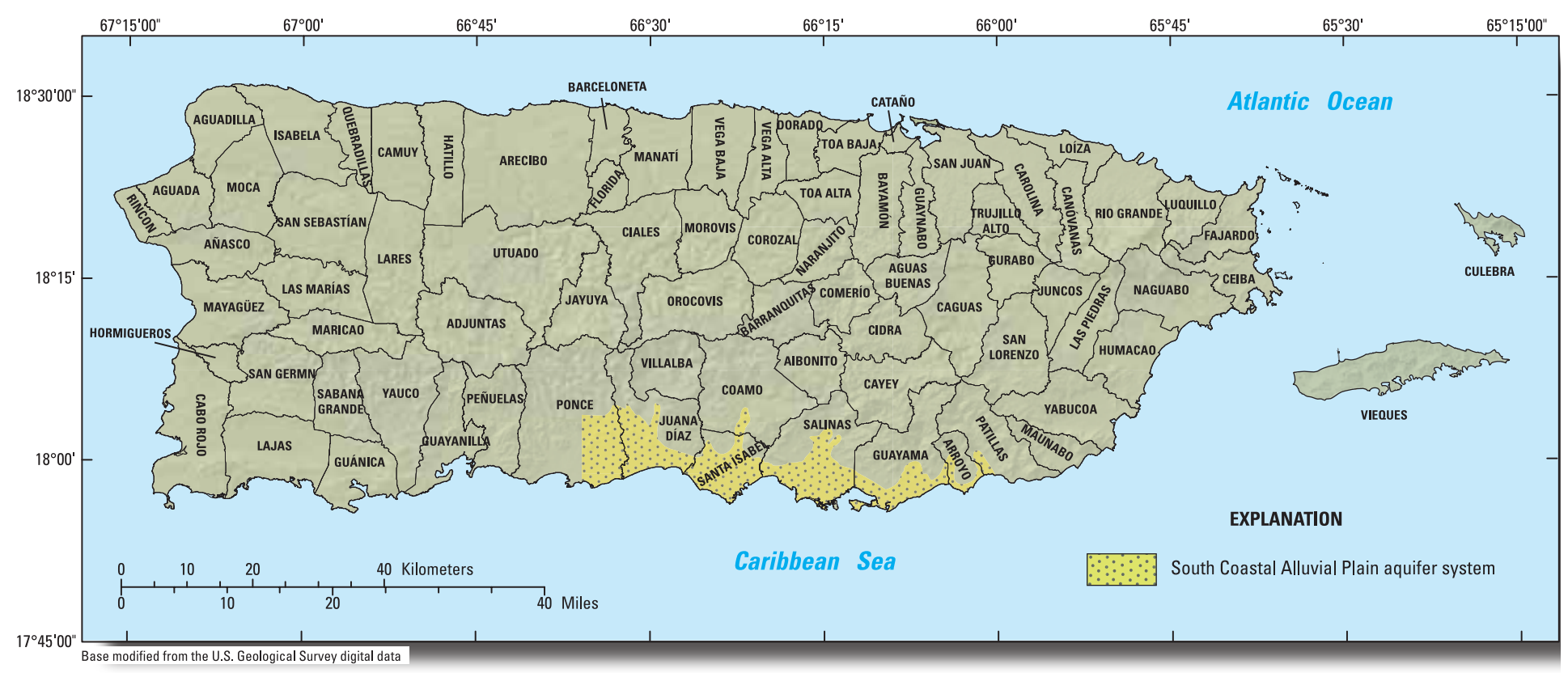

Figure 1. Location of municipios and the South Coastal Alluvial Plain aquifer system in Puerto Rico. 


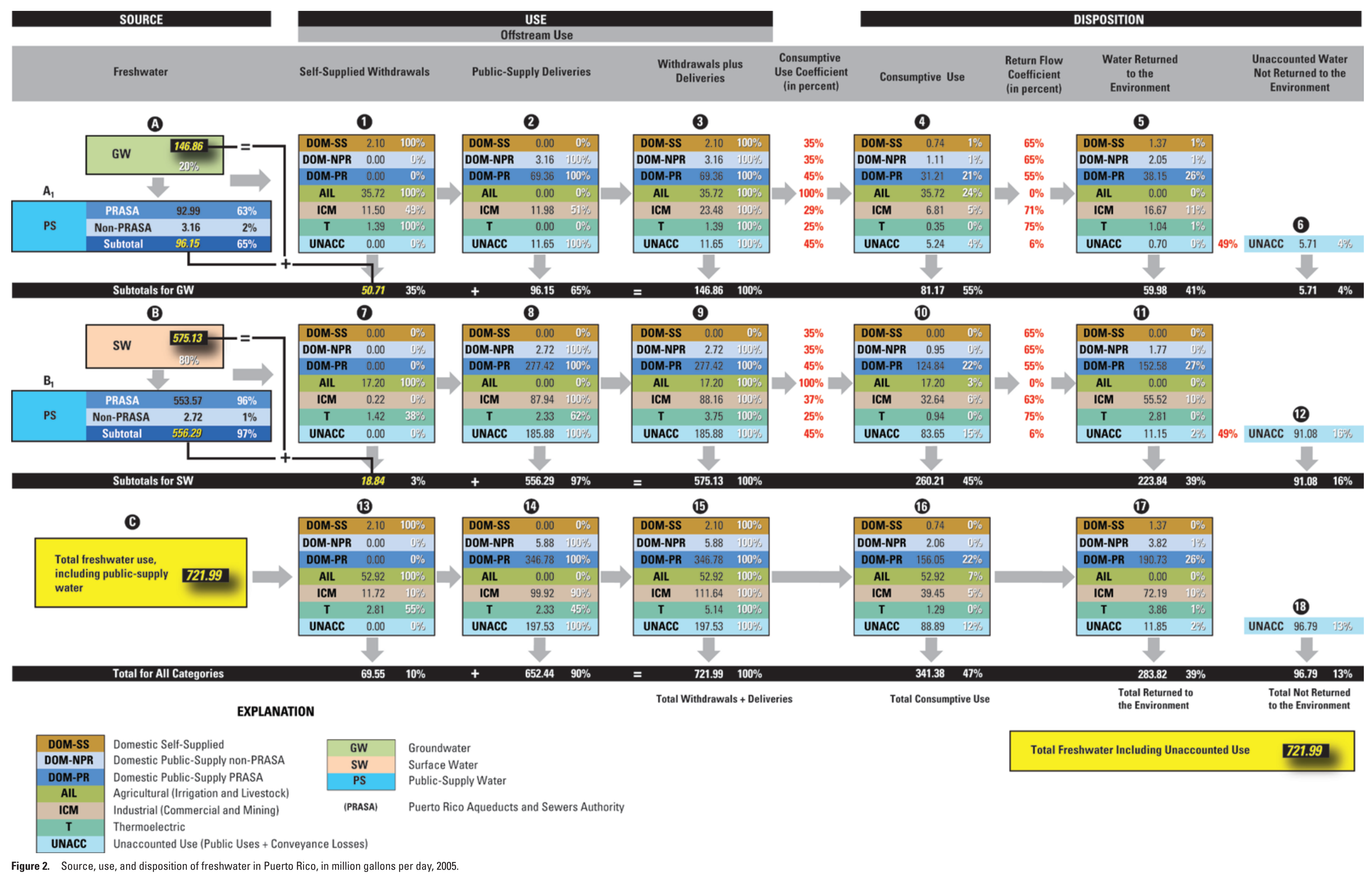


Groundwater sources provided about 146.9 Mgal/d (GW in box A, fig. 2) or 20 percent of the total freshwater withdrawn in Puerto Rico during 2005. About 96.2 Mgal/d (PS subtotal in box A1, fig. 2) or 65 percent were produced by public-supply water wells and $50.7 \mathrm{Mgal} / \mathrm{d}$ or 35 percent were obtained from self-supplied withdrawals.

Surface-water sources provided about 575.1 Mgal/d (SW in box B, fig. 2) or 80 percent of the total freshwater withdrawn in Puerto Rico during 2005. About 556.3 Mgal/d (PS subtotal in box B1, fig. 2) or 97 percent were produced by public-supply water facilities; the remaining $18.8 \mathrm{Mgal} / \mathrm{d}$ or 3 percent were self-supplied withdrawals.

\section{Use of Water}

Offstream use accounted for four major water-use categories: (1) domestic use (self-supplied withdrawals, nonPRASA and PRASA public-supply deliveries) represented as DOM-SS, DOM-NPR, DOM-PR in figure 2; (2) agriculture use (irrigation and livestock) represented as AIL in figure 2, (3) industrial use (commercial and mining) represented as ICM in figure 2, and (4) thermoelectric power use represented as $\mathrm{T}$ in figure 2. Public uses and conveyance losses were considered to be an unaccounted use and are represented as UNACC in figure 2.

\section{Domestic Use (Self-Supplied Withdrawals and Non-PRASA and PRASA Public-Supply Deliveries)}

Domestic use includes water used for indoor and outdoor household purposes, such as drinking, preparing food, bathing, washing clothes and dishes, flushing toilets, cleaning vehicles, and maintaining lawns and gardens. The domestic use combines the amount of water that is withdrawn by selfsupplied systems, in addition to the water that is delivered from public-supply water systems (non-PRASA and PRASA).

During 2005, the domestic self-supplied withdrawals were estimated at $2.10 \mathrm{Mgal} / \mathrm{d}$ (DOM-SS in box 13, fig. 2) to serve a population of 30,722 people, where groundwater was the only source of domestic self-supplied withdrawals. In addition the PRASA delivered 346.8 Mgal/d (DOM-PR in box 14, fig. 2) for domestic use to serve a population of 3.79 million inhabitants. Groundwater sources delivered 69.4 Mgal/d (DOM-PR in box 2, fig. 2) and surface-water sources delivered 277.4 Mgal/d (DOM-PR in box 8, fig. 2). On this basis, domestic per capita use was estimated at 92 gallons per day per person (gal/d-p). The non-PRASA systems provided 5.9 Mgal/d (DOM-NPR in box 14, fig. 2) to serve a population of about 86,492 people, thus estimating a domestic per capita use of 68 gal/d-p. Groundwater sources were estimated at 3.2 $\mathrm{Mgal} / \mathrm{d}$ (DOM-NPR in box 2, fig. 2) and surface-water sources were estimated at $2.7 \mathrm{Mgal} / \mathrm{d}$ (DOM-NPR in box 8, fig. 2).

\section{Agricultural Use (Irrigation and Livestock)}

Agricultural use includes the water applied for irrigation purposes and for livestock practices. The quantity of water withdrawn for agricultural use (irrigation and livestock) during 2005 was estimated at $52.9 \mathrm{Mgal} / \mathrm{d}$ (AIL in box 13, fig. 2), whereas $35.7 \mathrm{Mgal} / \mathrm{d}$ (AIL in box 1, fig. 2) were withdrawn for irrigation and livestock activities from groundwater sources.
Surface water provided 17.2 Mgal/d (AIL in box 7, fig. 2) for these activities. Groundwater and surface water from self-supplied sources satisfied the water requirements of 11.6 million animals (including poultry) in Puerto Rico during 2005 (U.S. Department of Agriculture, 2003).

Groundwater sources provided 30.01 Mgal/d for irrigation and 5.71 Mgal/d for livestock to total $35.7 \mathrm{Mgal} / \mathrm{d}$ (AIL in box 1, fig. 2), or 67 percent of the total freshwater withdrawn for agricultural use, mostly from the South Coastal Alluvial Plain aquifer system (fig. 1). Surface-water sources provided 15.15 $\mathrm{Mgal} / \mathrm{d}$ for irrigation and $2.08 \mathrm{Mgal} / \mathrm{d}$ for livestock to total 17.2 $\mathrm{Mgal} / \mathrm{d}$ (AIL in box 7, fig. 2), or 32 percent of the total water withdrawn. All of the surface-water withdrawn was provided by public irrigation districts, which are irrigation systems operated by the Puerto Rico Electric and Power Authority (PREPA), located in the southern and northwestern coasts of Puerto Rico. All reported irrigation withdrawals are identified as self-supplied although they were diverted from a public irrigation district.

\section{Industrial Use (Commercial and Mining)}

The combined industrial use category included the withdrawals for industries, commercial businesses, and mining facilities. Industrial use includes water used for manufacturing processes, such as fabrication, processing, washing, and cooling. Commercial use includes water used by hotels, restaurants, office buildings, commercial facilities, and civilian and military institutions. Mining use includes water used for the extraction of sand and gravel.

Total combined industrial use during 2005 was estimated at $111.6 \mathrm{Mgal} / \mathrm{d}$ (ICM in box 15, fig. 2). Self-supplied withdrawals accounted for $11.7 \mathrm{Mgal} / \mathrm{d}$ (ICM in box 13, fig. 2 ) or 10 percent of the total water withdrawn and delivered for the combined industrial use. The main source of the selfsupplied withdrawals for industrial use was groundwater. The remaining $99.9 \mathrm{Mgal} / \mathrm{d}$ (ICM in box 14, fig. 2) or 90 percent of the water used for industrial, commercial, and mining activities was from public-supply deliveries.

\section{Thermoelectric Power Water Use}

The thermoelectric power category includes water used in the generation of electric power with fossil-fuel energy. Although the largest amount of water used by the thermoelectric power facilities was from seawater sources, this amount was not considered in this factsheet because the salinewater withdrawal is considered an instream use. Freshwater withdrawals accounted for $5.1 \mathrm{Mgal} / \mathrm{d}$ ( $\mathrm{T}$ in box 15, fig. 2), of which self-supplied withdrawals accounted for $2.8 \mathrm{Mgal} / \mathrm{d}$ (T in box 13, fig. 2), and the remaining $2.3 \mathrm{Mgal} / \mathrm{d}$ ( $\mathrm{T}$ in box 14, fig. 2) was from public-supply deliveries.

\section{Unaccounted Use (Public Water Use and Conveyance Losses)}

The unaccounted water use combines the public-water use and the conveyance losses. Public-water use includes water used for non-individual consumption activities such as firefighting, street washing, and recreational activities at municipal parks. A conveyance loss is the term used for water that is lost while in transit from a pipe or canal system due to 
leakage or evaporation. Water that is lost due to groundwater leakage and/or percolates to an aquifer can become available and can be considered a return flow. This fact sheet includes the conveyance losses where water was lost while in transit from a pipe or canal system. An apparent loss is the term used for water that is delivered to customers but is not metered. This loss can occur due to unmetered systems, errors in water accounting, and unauthorized use of water.

Public-water use and conveyance losses accounted for $197.5 \mathrm{Mgal} / \mathrm{d}$ (UNACC in box 15, fig. 2) during 2005. Groundwater was the source for $11.6 \mathrm{Mgal} / \mathrm{d}$ (UNACC in box 3, fig. 2) delivered by public-water supply systems and 185.9 $\mathrm{Mgal} / \mathrm{d}$ (UNACC in box 9, fig. 2) was delivered from surface water systems. Forty-five percent or $88.9 \mathrm{Mgal} / \mathrm{d}$ (UNACC in box 16, fig. 2) of the total unaccounted use was consumed. About 6 percent or $11.8 \mathrm{Mgal} / \mathrm{d}$ (UNACC in box 17, fig. 2) was returned to the environment through underground leakage and/ or percolation into an aquifer. The remaining 49 percent or 96.8 $\mathrm{Mgal} / \mathrm{d}$ (UNACC in box 18, fig. 2) was lost or removed from the environment and is unavailable for further use.

\section{Disposition of Water}

The disposition columns in figure 2 show the proportion of water consumed (consumptive use) and the water that is returned to the environment (return flows). A specific consumptive use was estimated for each category by applying a coefficient. Table 1 contains the estimated consumptive use for Puerto Rico by source and category during 2005.

The consumptive use for each category was calculated applying the following equation:

\section{Consumptive Use in Mgal/d= (Withdrawals + Deliveries $)$ $x$ Consumptive-Use Coefficient}

Consumptive-use coefficients were applied based on previous water-use compilations (Solley and others, 1998). For example, consumptive use for domestic public-supply water PRASA (Domestic PRASA in table 1) was estimated as 45 percent, 10 percent more than in domestic public-supply water non-PRASA and domestic self-supplied that was estimated at 35 percent. This difference exists because the people that are served from domestic public-supply water systems have an elevated per capita use (92 gal/d-p) and consequently, a higher consumptive use rate (45 percent of total withdrawals and deliveries).
The consumptive-use coefficient for agricultural use (irrigation and livestock) was 100 percent (table 1). Puerto Rico has the highest estimated mean evapotranspiration in the United States (45 inches per year) (Hanson, 1991); therefore, all of the water withdrawn for agricultural activities in Puerto Rico was considered to be consumed and return flows were not accounted for in this category.

Water returned to the environment was calculated applying a return flow coefficient. The following equation was applied to calculate the water return to the environment:

\section{Water returned to environment in $\mathrm{Mgal} / \mathrm{d}=$ (Withdrawals + Deliveries) $x$ Return Flow Coefficient}

The total freshwater withdrawn and delivered during 2005 was $341.4 \mathrm{Mgal} / \mathrm{d}$ or 47 percent for consumptive use. An estimated $283.8 \mathrm{Mgal} / \mathrm{d}$ or 39 percent was returned to the environment, mainly through wastewater treatment plants. The remaining $96.8 \mathrm{Mgal} / \mathrm{d}$ or 13 percent was unaccounted use that was lost and not returned to the environment for further use (fig. 2).

\section{Reference Cited}

Hanson, R.L., 1991, Evapotranspiration and droughts, in Paulson, R.W., Chase, E.B., Roberts, R.S., and Moody, D.W., Compilers, National Water Summary 1988-89-Hydrologic Events and Floods and Droughts: U.S. Geological Survey Water-Supply Paper 2375, p. 99-104: accessed June 2009 at http://geochange.er.usgs.gov/sw/change/natural/et

Molina-Rivera, W.L., and Gómez-Gómez, F., 2008, Estimated water use in Puerto Rico, 2005: U.S. Geological Survey Open-file report 2008-1286, 37 p.: accessed August 2009 at http://pubs.usgs.gov/of/2008/1286/

Solley, W.B., Pierce, R.R., and Perlman, H.A., 1998, Estimated use of water in the United States in 1995: U.S. Geological Survey Circular 1200, 71 p.

U.S. Census Bureau, 2006, Population Division, Annual Estimates of the population for municipios of Puerto Rico: April, 2000 to July 1, 2005 (PRM-EST 2005-01).

U.S. Department of Agriculture, 2003, 2002 Census of Agriculture, Puerto Rico municipio profiles: accessed August 2004 at www.nass.usda.gov/census/census02/ puertorico/profiles/index.htm

Table 1. Estimated consumptive use coefficient for Puerto Rico, 2005.

[PRASA, Puerto Rico Aqueducts and Sewers Authority]

\begin{tabular}{|lcc}
\hline \multirow{2}{*}{ Water-use categories } & \multicolumn{1}{c}{ Consumptive-use coefficient by source of water (in percent) } \\
\cline { 2 - 3 } & Groundwater & Surface water \\
\hline Domestic (self-supplied and non-PRASA) & 35 & 35 \\
\hline Domestic (PRASA) & 45 & 45 \\
\hline Agriculture (irrigation and livestock) & 100 & 100 \\
\hline Industrial (commercial and mining) & 29 & 37 \\
\hline Thermoelectric & 25 & 25 \\
\hline
\end{tabular}




\section{Puerto Rico 2005 Water - Use Facts}

- Offstream uses totaled 722 million gallons per day.

- Surface water provided 575 million gallons per day, or 80 percent, and groundwater provided 147 million gallons per day, or 20 percent, of the total offstream water used in Puerto Rico.

- The average amount of domestic water used per person per day was 92 gallons.

- A total of 45 percent of the water produced for domestic use by public-supply water systems was consumed.

- Irrigation water use was estimated as 45 million gallons per day with 66 percent obtained from aquifers.

- The mean annual evapotranspiration rate for Puerto Rico was estimated as 45 inches per year. This is the highest evapotranspiration rate in the United States.

- All of the water (100 percent) used for agricultural purposes (irrigation and livestock) was consumed.

\section{ZUSES}

Estimated Water Use in Puerto Rico, 2005

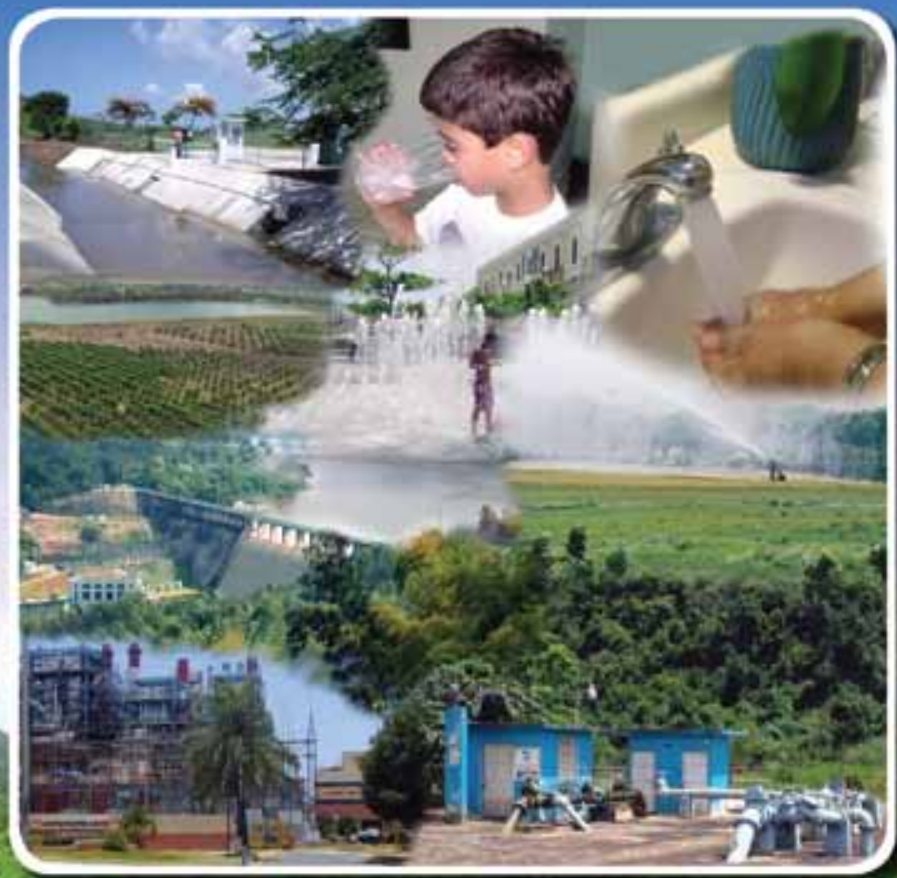

Question or request for additional data related to water use in Puerto Rico can be directed to the author:

Wanda L. Molina-Rivera

U.S. Geological Survey

GSA Center, bldg 651 Federal Drive, Suite 400-15

Guaynabo, P.R. 00965-5703

(787) $749-4346$ ext. 259

wlmolina@usgs.gov

Additional information is available in

the publication "Estimated Water Use in Puerto Rico, 2005" at http://pubs.usgs.gov/ of/2008/1286/

\section{Open-File Report $2008=1286$}

\section{U.S. Geological Survey}

Suzette M. Kimball, Acting Director 